\title{
Ergosterol Peroxide and Stigmasterol from The Stembark of Aglaia simplicifolia (Meliaceae) and Their Cytotoxic against HeLa Cervical Cancer Cell Lines
}

\author{
Nunung Kurniasih ${ }^{1 *}$, Asep Supriadin ${ }^{1}$, Desi Harneti², Rizky Abdulah ${ }^{3}$, Mohamad Nurul \\ Azmi bin Mohamad Taib ${ }^{4}$, Unang Supratman ${ }^{2,5}$ \\ ${ }^{1}$ Department of Chemistry, Faculty of Sciences and Technology, Sunan Gunung Djati Islamic State University \\ Bandung 40614, Indonesia \\ ${ }^{2}$ Department of Chemistry, Faculty of Mathematics and Natural Sciences, Universitas Padjadjaran \\ Jatinangor 45363, Indonesia \\ ${ }^{3}$ Department of Pharmacology and Clinical Pharmacy, Faculty of Pharmacy, Universitas Padjadjaran \\ Jatinangor 45363, Indonesia \\ ${ }^{4}$ School of Chemical Sciences, Universiti Sains Malaysia \\ 11800 Minden, Penang, Malaysia \\ ${ }^{5}$ Central Laboratory of Universitas Padjadjaran \\ Jatinangor 45363, Indonesia \\ *orresponding author: nunungkurniasih@uinsgd.ac.id
}

Received: March 2021; Revision: March 2021; Accepted: June 2021; Available online: June 2021

\begin{abstract}
Two steroid compounds, ergosterol peroxide (1) and stigmasterol (2) have been isolated from the stembark of Aglaia simplicifolia belong to Meliaceae family. The chemical structures of $\mathbf{1}$ and $\mathbf{2}$ were identified based on spectroscopic evidence including UV, IR, 1D NMR, 2D NMR as well as mass spectra and by comparison with those previously reported spectra data. Both compounds were evaluated for their cytotoxic effects against cervical cancer HeLa cells in vitro. Compounds $\mathbf{1}$ and $\mathbf{2}$ showed cytotoxicity activity against HeLa cervical cancer cells with $\mathrm{IC}_{50}$ values of 0.80 and $26.42 \mu \mathrm{M}$, respectively.
\end{abstract}

Keywords : Ergosterol peroxide, stigmasterol, Aglaia simplicifolia, HeLa cervical cancer, IC $_{50}$

DOI: $10.15408 / j k v \cdot v 7 i 1.20068$

\section{INTRODUCTION}

Meliaceae is the important plant families that have utilized and generally grow in tropical countries. Meliaceae plant is known for the presence of the various secondary metabolite compounds that exhibit interesting biological activity such as hypoglycemia, anticancer, anti-inflammation, antifeedant, antitumor (Awang et al., 2012; Leong et al., 2016; Su et al., 2006) and insecticidal activity (Nugroho et al., 1999).

The Aglaia genus is a plant of the tropical rain forest in the Indomalesiana region and mainly distributed in tropical countries including India, Indonesia, Malaysia and parts of the Western Pacific. Aglaia is the largest genus belongs to the Meliaceae family contains more than 150 species (Hidayat et al., 2017a;
Hidayat et al., 2017b; Awang et al., 2012) and about 65 species grown in Indonesia (Wood, et al., 1970; Heyne 1982). Phytochemical studies on Aglaia species have led to the identification of main compounds such as sesquiterpenoid, diterpenoid, triterpenoid, limonoid, steroid, lignan, and alkaloid groups (Harneti \& Supratman, 2021).

Aglaia simplicifolia is found in Sumatra and Kalimantan, Indonesia. So far, reports on the content of secondary metabolite compounds from this plant are the only senecracidiol isolated from the bark of the stem (Kurniasih et al., 2019). Although steroids of other Aglaia species have been investigated previously, the ergosterol peroxide of $A$. simplicifolia is yet to be reported. 


\section{MATERIALS AND METHOD Tools and Materials}

Thin layer chromatography (TLC): silica gel plates (GF254, Merck, $0.25 \mathrm{~mm}$ ); visualized by heating and immersing in $10 \%$ $\mathrm{H}_{2} \mathrm{SO}_{4}$ in EtOH. Column chromatography (CC): commercial $\mathrm{SiO}_{2}(100-200$ and $200-$ 300 mesh; Merck, Darmstadt, Germany), and reversed-phase $\mathrm{C} 18\left(\mathrm{RP}_{-} \mathrm{C}_{18} ; 40-63 \mathrm{~mm}\right.$; Fuji Sylisia, Japan); fractions were monitored by TLC. IR Spectra: Perkin-Elmer spectrum100 FT-IR (Waltwam, MA, USA); KBr disks. ${ }^{1} \mathrm{H}$ - and ${ }^{13} \mathrm{C}-\mathrm{NMR}$ spectra: Bruker Topspin spectrometer at 500 and $125 \mathrm{MHz}$ respectively (Bruker BioSpin GmbH, Silberstreifen 4, D76287 Rheinstetten, Germany); in $\mathrm{CDCl}_{3}$; at room temperature; $d$ in ppm relative to $\mathrm{Me}_{4} \mathrm{Si}$ as internal standard, $\mathrm{J}$ in $\mathrm{Hz}$. HR-TOF-MS: Synapt G2 mass spectrometer instrument (Waters, Milford, MA, USA); in m/z.

Cervical cancer line HeLa was maintained in RPMI-1640 medium (Gibco) supplemented with $10 \%$ fetal bovine serum (FBS) and $1 \%$ pen strep (Gibco). Cultures were grown in a humidified incubator at $37^{\circ} \mathrm{C}$ and $5 \% \mathrm{CO}_{2}$. The stembark collected from Bogor Botanical Garden and taxonomically identified as A. simplicifolia by Mr. Didik Widyatmoko. A voucher specimen (No. BO1295311) was deposited in Bogoriense Herbarium, Bogor, West Java Province, Indonesia.

\section{Extraction and Isolation}

Air-dried stems $(1.10 \mathrm{~kg}) \quad$ were extracted three times with $\mathrm{MeOH}(3 \times 4 \mathrm{~L} ; 3 \mathrm{~h}$, $3 \mathrm{~h}$, and $2 \mathrm{~h}$, respectively) at room temperature. After removal of $\mathrm{MeOH}$ under reduced pressure with a rotary evaporator, the viscous residue was suspended in $\mathrm{H}_{2} \mathrm{O}: \mathrm{MeOH}$ (4:1) and partitioned successively with $n$-hexane (10 $\mathrm{L})$, ethyl acetate $(10 \mathrm{~L})$, and $n$-butanol $(10 \mathrm{~L})$. Evaporated of these extracts resulted of $n$ hexane $(14.5 \mathrm{~g})$, ethyl acetate $(28.0 \mathrm{~g})$ and $n$ butanol $(14.5 \mathrm{~g})$, respectively.

The $n$-hexane -soluble extract $(14.5$ g) was fractionated by vacuum liquid chromatography (silica gel G60; aq. $n$-hexaneethyl acetate-methanol, gradient) to give nine fractions, Frs. A - I, combined according to the TLC results. Fraction D (1.29 g) was further subjected to column chromatography $\left(\mathrm{SiO}_{2} ; n\right.$ hexane-ethyl acetate 100:0 to 40:60, gradient) to give nine subfractions, Frs. D.1 - D.9. Fraction C.6 (142.3 mg) was subjected to CC
$\left(\mathrm{SiO}_{2}\right.$; methylene chloride: ethyl acetate (49: 1) to yield compound $1(5.6 \mathrm{mg})$. Fraction D.7 $(109.0 \mathrm{mg})$ was separated by $\mathrm{CC}\left(\mathrm{SiO}_{2}\right.$; methylene chloride: ethyl acetate (49: 1) to yield 2 (20.6 mg).

\section{Cytotoxic Activity (Resazurin assay)}

Cell viability was assessed by resazurin assay following the previously reported procedures (Sittampalam et al., 2004). Cells were seeded into a 96-well plates at a density of 17,000 cells/well and stabilized at $37{ }^{\circ} \mathrm{C}$ in $5 \% \mathrm{CO}_{2}$ for $24 \mathrm{~h}$. Cells were incubated for $24 \mathrm{~h}$ with compounds $\mathbf{1}$ and $\mathbf{2}$. Ten cells were treated with $10 \mu \mathrm{L}$ of Presto Blue ${ }^{\mathrm{TM}}$ Cell Viability Reagent for another 1-2 hours. Cell viability assessed by measuring the absorbance at $570 \mathrm{~nm}$ with a reference wavelength of $600 \mathrm{~nm}$ using an EMax Microplate Reader (Molecular Devices, Sunnyvale, CA, USA). For the positive control, cells were incubated for $24 \mathrm{~h}$ with 100 $\mu \mathrm{L}$ of Cisplatin.

\section{RESULT AND DISCUSSION Structure Elucidation}

In our phytochemical research on Aglaia simplicifolia, two steroids, ergosterol peroxide (1) and stigmasterol (2) (Figure 1) were isolated from the nonpolar fractions. Their structures were determined by a detailed analysis of their spectroscopic data.

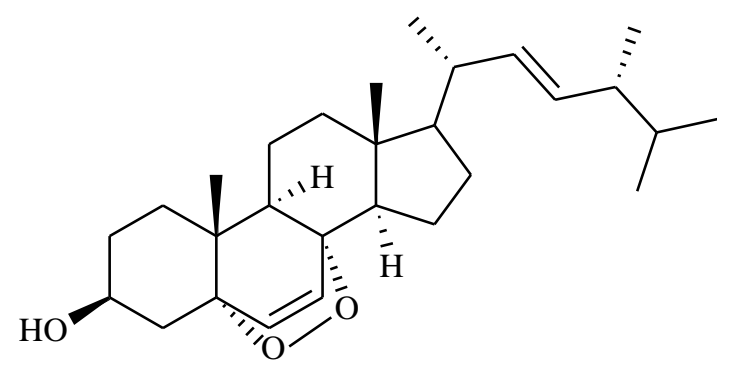

(1)

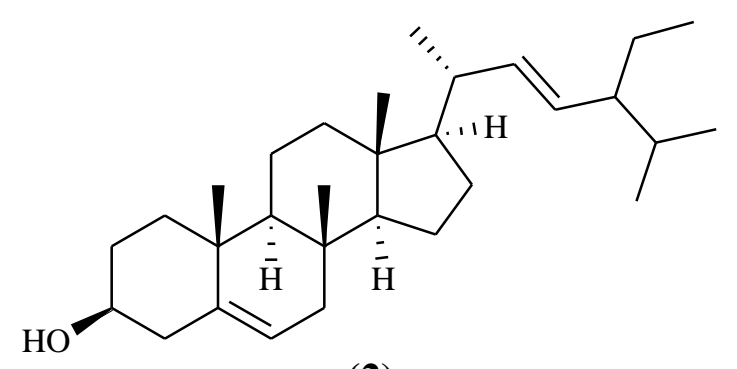

(2)

Figure 1. Chemical structures of compounds 1 and 2 
Table 1. NMR data for compounds 1 and $2\left(\mathrm{CDCl}_{3}, 500 \mathrm{MHz}\right.$ for ${ }^{1} \mathrm{H}$ and $125 \mathrm{MHz}$ for $\left.{ }^{13} \mathrm{C}\right)$ compared with Ergosterol Peroxide (Nowak et al., 2016) and Stigmasterol (Cayme \& Ragasa, 2004)

\begin{tabular}{|c|c|c|c|c|c|c|c|c|}
\hline \multirow{2}{*}{$\begin{array}{l}\text { Posi } \\
\text { tion }\end{array}$} & \multicolumn{2}{|c|}{ Compound (1) } & \multicolumn{2}{|c|}{ Ergosterol peroxide ${ }^{*}$} & \multicolumn{2}{|c|}{ Compound (2) } & \multicolumn{2}{|c|}{ Stigmasterol $^{* * *}$} \\
\hline & $\begin{array}{c}{ }^{1} \mathrm{H} \text { NMR } \\
\delta_{\mathrm{H}}(\text { Integral, } \\
\text { mult, } J=\mathrm{Hz})\end{array}$ & $\delta^{13} \mathrm{C}$ & $\begin{array}{c}{ }^{1} \mathbf{H} \text { NMR } \\
\delta_{\mathrm{H}}(\text { Integral, } \\
\text { mult, } J=\mathbf{H z})\end{array}$ & $\delta^{13} \mathrm{C}$ & $\begin{array}{c}{ }^{1} \mathrm{H} \text { NMR } \\
\delta_{\mathrm{H}} \text { (Integral, } \\
\text { mult, } J=\mathbf{H z} \text { ) }\end{array}$ & $\delta^{13} \mathrm{C}$ & $\begin{array}{r}{ }^{1} \text { H NMR } \\
\delta_{H}(\text { Integral, } \\
\text { mult, } J=H z)\end{array}$ & $\delta^{13} \mathrm{C}$ \\
\hline 1 & $\begin{array}{l}1.70, \mathrm{dd}, \mathrm{J}= \\
13.8 ; 3.4\end{array}$ & 34.71 & $\begin{array}{l}1.73, \mathrm{dd}, \mathrm{J}= \\
13.8 ; 3.4\end{array}$ & 34.7 & $\begin{array}{l}1.08, \mathrm{~m} ; 1.84, \\
\mathrm{~m}\end{array}$ & $37.4(\mathrm{t})$ & $\begin{array}{c}1.73, \mathrm{dd}, \mathrm{J}= \\
13.8 ; 3.4\end{array}$ & 34.7 \\
\hline 2 & - & 30.13 & & 30.1 & $1.49, \mathrm{~m} ; 1.81, \mathrm{~m}$ & $31.8(\mathrm{t})$ & & 30.1 \\
\hline 3 & $3.95, \mathrm{~m}$ & 66.47 & $3.98, \mathrm{~m}$ & 66.5 & $3.52, \mathrm{~m}$ & $72.0(\mathrm{~d})$ & $3.98, \mathrm{~m}$ & 66.5 \\
\hline 4 & - & 36.98 & & 37.0 & $\begin{array}{l}2.28, \mathrm{dd}, \mathrm{J}= \\
2.0 ; 5.2 \\
2.30, \mathrm{dd}, \mathrm{J}= \\
2.0 ; 5.2\end{array}$ & $42.5(\mathrm{t})$ & & 37.0 \\
\hline 5 & - & 82,15 & & 82.2 & - & $\begin{array}{l}140.9 \\
(\mathrm{~s})\end{array}$ & & 82.2 \\
\hline 6 & $6.22, \mathrm{~d}, \mathrm{~J}=8.5$ & 135.41 & $6.25, \mathrm{~d}, \mathrm{~J}=8.5$ & 135.4 & $5.35, \mathrm{~d}, \mathrm{~J}=5.2$ & $\begin{array}{l}121.9 \\
\text { (d) }\end{array}$ & $6.25, \mathrm{~d}, \mathrm{~J}=8.5$ & 135.4 \\
\hline 7 & $6.51, \mathrm{~d}, \mathrm{~J}=8.6$ & 130.75 & $6.52, \mathrm{~d}, \mathrm{~J}=8.6$ & 130.8 & $1.54, \mathrm{~m} ; 1.96, \mathrm{~m}$ & $32.1(\mathrm{t})$ & $6.52, \mathrm{~d}, \mathrm{~J}=8.6$ & 130.8 \\
\hline 8 & - & 79.42 & & 79.4 & $1.46, \mathrm{~m}$ & $32.0(\mathrm{~d})$ & & 79.4 \\
\hline 9 & - & 51.13 & & 51.1 & $0.94, \mathrm{~m}$ & $50.3(d)$ & & 51.1 \\
\hline 10 & - & 36.95 & & 36.9 & - & $36.7(\mathrm{~s})$ & & 36.9 \\
\hline 11 & $1.21, \mathrm{~m} ; 1.55, \mathrm{~m}$ & 20.63 & $1.23, \mathrm{~m} ; 1.55, \mathrm{~m}$ & 20.6 & $1.46, \mathrm{~m} ; 1.49, \mathrm{~m}$ & $21.3(\mathrm{t})$ & $1.23, \mathrm{~m} ; 1.55, \mathrm{~m}$ & 20.6 \\
\hline 12 & $1.25, \mathrm{~m} ; 1.98, \mathrm{~m}$ & $\begin{array}{l}39.36 \\
44.57\end{array}$ & $1.27, \mathrm{~m} ; 1.98, \mathrm{~m}$ & 39.4 & $1.15, \mathrm{~m} ; 1.95, \mathrm{~m}$ & $39.9(\mathrm{t})$ & $1.27, \mathrm{~m} ; 1.98, \mathrm{~m}$ & 39.4 \\
\hline 14 & $1.55, \mathrm{~m}$ & 51.69 & $1.59, \mathrm{~m}$ & 51.7 & $1.03, \mathrm{~m}$ & $56.9(\mathrm{~d})$ & $1.59, \mathrm{~m}$ & 51.7 \\
\hline 15 & $1.42, \mathrm{~m} ; 1.66, \mathrm{~m}$ & 23.40 & $1.42, \mathrm{~m} ; 1.66, \mathrm{~m}$ & 23.4 & $1.07, \mathrm{~m} ; 1.56, \mathrm{~m}$ & $24.5(\mathrm{t})$ & $1,42, \mathrm{~m} ; 1,66, \mathrm{~m}$ & 23.4 \\
\hline 16 & $1.32, \mathrm{~m} ; 1.81, \mathrm{~m}$ & 28.62 & $1.33, \mathrm{~m} ; 1.81, \mathrm{~m}$ & 28.7 & $1.26, \mathrm{~m} ; 1.67, \mathrm{~m}$ & $28.4(\mathrm{t})$ & $1.33, \mathrm{~m} ; 1.81, \mathrm{~m}$ & 28.7 \\
\hline 17 & $1.25, \mathrm{~m}$ & 56.23 & $1.25, \mathrm{~m}$ & 56.2 & $1.13, \mathrm{~m}$ & $56.1(\mathrm{~d})$ & $1.25, \mathrm{~m}$ & 56.2 \\
\hline 18 & $0.81 \mathrm{~s}$ & 12.87 & $0.83, \mathrm{~s}$ & 12.9 & $0.67, \mathrm{~s}$ & $12.1(q)$ & $0.83, \mathrm{~s}$ & 12.9 \\
\hline 19 & $0.83 \mathrm{~s}$ & 18.16 & $0.89, \mathrm{~s}$ & 18.2 & $1.00, \mathrm{~s}$ & $19.5(q)$ & $0.89, \mathrm{~s}$ & 18.2 \\
\hline 20 & $2.03, \mathrm{~m}$ & 39.69 & $2.05, \mathrm{~m}$ & 39.7 & $2.02, \mathrm{~m}$ & $40.7(\mathrm{~d})$ & $2.05, \mathrm{~m}$ & 39.7 \\
\hline 21 & $1.17, \mathrm{~d}, \mathrm{~J}=6.7$ & 20.87 & $1.00, \mathrm{~d}, \mathrm{~J}=6.7$ & 20.9 & $0.92, \mathrm{~d}, \mathrm{~J}=6.5$ & $21.2(q)$ & $1.00, \mathrm{~d}, \mathrm{~J}=6.7$ & 20.9 \\
\hline 22 & $\begin{array}{l}5.17, \mathrm{dd}, \mathrm{J}=7.5 \\
15.3\end{array}$ & 135.19 & $\begin{array}{l}5.16, \mathrm{dd}, \mathrm{J}= \\
7.5 ; 15.3\end{array}$ & 135.2 & $\begin{array}{l}5.16, \mathrm{dd}, \mathrm{J}= \\
8.5 ; 15.0\end{array}$ & $\begin{array}{l}138.5 \\
\text { (d) }\end{array}$ & $\begin{array}{c}5.16, \mathrm{dd}, \mathrm{J}=7.5 \\
15.3\end{array}$ & 135.2 \\
\hline 23 & $\begin{array}{l}5.11, \mathrm{dd}, \mathrm{J}=8.0 \\
15.3\end{array}$ & 132.33 & $\begin{array}{l}5.14, \mathrm{dd}, \mathrm{J}= \\
8.0 ; 15.3\end{array}$ & 132.3 & $\begin{array}{l}5.00, \mathrm{dd}, \mathrm{J}= \\
8.5 ; 15.0\end{array}$ & $\begin{array}{l}129.5 \\
\text { (d) }\end{array}$ & $\begin{array}{c}5.14, \mathrm{dd}, \mathrm{J}=8.0 \\
15.3\end{array}$ & 132.3 \\
\hline 24 & $1.88, \mathrm{~m}$ & 42.78 & $1.86, \mathrm{~m}$ & 42.8 & $1.53, \mathrm{~m}$ & $51.4(\mathrm{~d})$ & $1.86, \mathrm{~m}$ & 42.8 \\
\hline 25 & $1.62, \mathrm{~m}$ & 33.07 & $1.6, \mathrm{~m}$ & 33.1 & $1.45, \mathrm{~m}$ & $31.8(\mathrm{~d})$ & $1,6, \mathrm{~m}$ & 33.1 \\
\hline 26 & $0.84, \mathrm{~d}, \mathrm{~J}=6.8$ & 19.63 & $0.82, \mathrm{~d}, \mathrm{~J}=6.8$ & 19.6 & $0.84, \mathrm{~d}, \mathrm{~J}=6.4$ & $21.3(q)$ & $0.82, \mathrm{~d}, \mathrm{~J}=6.8$ & 19.6 \\
\hline 27 & $0.87, \mathrm{~d}, \mathrm{~J}=6.6$ & 19.93 & $0.83, \mathrm{~d}, \mathrm{~J}=6.6$ & 20.0 & $0.82, \mathrm{~d}, \mathrm{~J}=6.1$ & $19.1(q)$ & $0.83, \mathrm{~d}, \mathrm{~J}=6.6$ & 20.0 \\
\hline $\begin{array}{l}28 \\
29\end{array}$ & $0.93, \mathrm{~d}, \mathrm{~J}=6.8$ & 17.55 & $0.91, \mathrm{~d}, \mathrm{~J}=6.8$ & 17.6 & $\begin{array}{l}1.15, \mathrm{t}, \mathrm{J}=3.2 \\
0.80, \mathrm{t}, \mathrm{J}=6.0\end{array}$ & $\begin{array}{l}25.6(d) \\
12.2(q)\end{array}$ & $0.91, \mathrm{~d}, \mathrm{~J}=6.8$ & 17.6 \\
\hline
\end{tabular}

Compound 1 was obtained as colorless needles with a melting point between 179-182 ${ }^{\circ} \mathrm{C}$. The HR-TOF-MS result at $\mathrm{m} / \mathrm{z} 451.3748$ $\left(\left[\mathrm{M}+\mathrm{Na}^{+}\right]\right.$; calc. 428.3704$)$ indicated that it has a molecular formula of $\mathrm{C}_{28} \mathrm{H}_{44} \mathrm{O}_{3}$ with seven degrees of unsaturation. The IR spectrum showed the functional group of hydroxyl $\left(3401 \mathrm{~cm}^{-1}\right)$ and ether groups (1052 
$\mathrm{cm}^{-1}$ ). The 13C-NMR spectrum showed 28 carbons signals (Table 1), which could be classified with the help of HSQC data as six $\mathrm{Me}$, seven $\mathrm{CH}_{2}$, and eleven $\mathrm{CH}$ groups (two oxygenated), and four $\mathrm{Cq}$-atoms. The presence of two disubstituted olefins ( $\delta 130.78$ (C-7), 132.33 (C-23), 135.41 (C-6), 135.19 (C-22)), indicating that the sterol fragment of compound $\mathbf{1}$ is an ergosterol derivative. Besides, two oxygenated quaternary carbons of $\delta 82.15(\mathrm{C}-5)$ and 79.42 (C-8) suggested the presence of a peroxide structure.

The signals at $\delta_{\mathrm{H}} 6.22$ and $6.51(\mathrm{~d}, \mathrm{~J}=$ $8 \mathrm{~Hz}, 2 \mathrm{H}, \mathrm{H}-6, \mathrm{H}-7$ ) in the ${ }^{1} \mathrm{H}-\mathrm{NMR}$ spectrum revealed the presence of a disubstituted double bond which were correlated with carbon signals of 135.41 (C-6) and 130.78 (C-7) in the HMBC spectrum. The ${ }^{1} \mathrm{H}-\mathrm{NMR}$ showed also signals for six methyl groups, two singlets at 0.81 and 0.83 , and four doublets at $0.84(\mathrm{~J}=$ $6.8 \mathrm{~Hz}), 0.87(\mathrm{~J}=6.6 \mathrm{~Hz}), 0.93(\mathrm{~J}=6.8 \mathrm{~Hz})$ and $1.17(\mathrm{~J}=6.7 \mathrm{~Hz})$. Moreover, a multiplet at 3.95, characteristic of a steroid oxymethine signal located at C-3, was observed. The 2DNMR experiments confirmed that compound $\mathbf{1}$ is a steroid, containing a peroxy function at $\mathrm{C}$ 5/C-8 and two double bonds in the side chain and at C-6/C-7.

In the HMBC correlations (Figure 2), these three methylene proton signals were correlated to the methine carbon signal at $\delta_{\mathrm{C}}$ 66.84 (C-3), and the methylene carbon signal at $\delta_{\mathrm{C}} 35.06(\mathrm{C}-1)$ was correlated with the methyl proton signal at $\delta_{\mathrm{H}} 0.89(\mathrm{H}-19)$. The methylene proton signals at $\delta_{\mathrm{H}} 1.94$ and 2.11 $(\mathrm{H}-4)$ were clearly correlated to two carbon signals at $\delta_{\mathrm{C}} 83.10(\mathrm{C}-5)$ and $135.80(\mathrm{C}-6)$ in $5 \alpha, 8 \alpha$-epidioxy system. The methyl proton signal at $\delta_{\mathrm{H}} 0.89$ (H-19) was long-rangecorrelated to the methyne carbon signal at $\delta_{\mathrm{C}}$ $83.10(\mathrm{C}-5)$ to which the proton signals at $\delta_{\mathrm{H}}$ 1.94 and $2.11(\mathrm{H}-4)$ were correlated, but not to the signal at $\delta_{\mathrm{C}} 79.82(\mathrm{C}-8)$. The methyl proton signal was also correlated to the methine carbon signal at $\delta_{\mathrm{C}} 51.43$ (C-9), but not to the signal at 52.05 (C-14) which correlated with the methyl proton signal at $\delta_{\mathrm{H}} 0.83(\mathrm{H}-18)$. Also an olefinic proton signal in $5 \alpha, 8 \alpha-$ epidioxy system at (5 6.25 (H-7) was correlated to the carbon signals at $\delta_{\mathrm{C}} 51.43$ (C9) and 52.05 (C- 14), while the other olefinic proton signal at $\delta_{\mathrm{H}} 6.51(\mathrm{H}-6)$ was correlated to carbon signals at $\delta_{\mathrm{C}} 37.29(\mathrm{C}-4)$ and 37.33 (C-10). Therefore, the structure of ergosterol peroxide (5,8-epidioxy-5 ,8 -ergosta-6,22E- dien-3 -ol) was thus elucidated to be $\mathbf{1}$. In this paper ergosterol peroxide was isolated from $A$. simplicifolia first time, so it is a new compound for this species. The known compounds stigmasterol (2), were confirmed by comparison and biogenetic analysis of these compounds with values reported by Cayme \& Ragasa (2004).

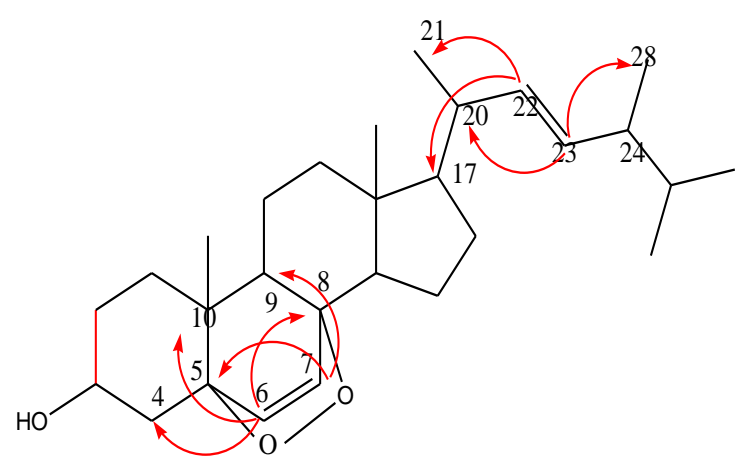

Figure 2. The long-range correlations of ergosterol peroxide through three bond connections observed in HMBC. All proton signals were correlated to carbon signals through two bond connections except $\mathrm{H}-3, \mathrm{H}-16$ and $\mathrm{H}-17$. The arrow indicates the correlation from proton to carbon.

\section{Cytotoxic Activity}

The cytotoxic effects of compounds 1 and $\mathbf{2}$ against HeLa cervical cancer cells were conducted according to the resazurin assay method (Sittampalam et al., 2004) and were used cisplatin $\left(\mathrm{IC}_{50} 0.67 \mu \mathrm{M}\right)$ as a positive control. As shown in Figure 3, treatment with both compounds resulted in the dosedependent inhibition of HeLa cervical cancer cell growth when assessed at 24 hours posttreatment. Higher concentrations of both compounds were required to inhibit cell growth.

Ergosterol peroxide (1) has a much stronger activity with an $\mathrm{IC}_{50}$ value of $0.80 \mu \mathrm{M}$ compared to stigmasterol (2) which has an $\mathrm{IC}_{50}$ value of $26.42 \mu \mathrm{M}$. This shows that the value of cytotoxic activity against HeLa cervical cancer cells is influenced by the presence of peroxide groups bound to C-5 and C-8. In fact, the ergosterol peroxide compound from the stem bark of Aglaia simplicifolia is much stronger to inhibit the growth of cervical cancer cells $\mathrm{HeLa}$ than those isolated from marine fungus Phoma sp with an $\mathrm{IC}_{50}$ value of $29.20 \mu \mathrm{M}$ (Wu et al., 2018).

Ergosterol peroxide was sensitive to cancer cells, while less sensitive or nontoxic to normal cells. Wu et al., (2018) isolated 
ergosterol peroxide from marine fungus Phoma sp. The bioassay results demonstrated that ergosterol peroxide reduced the viability of various cancer cells. EP induced caspasedependent apoptosis through mitochondrial damage, induced ROS generation and apoptosis, and reduced the LPS/ATP induced proliferation and migration of A549 cells through attenuated NLRP3 inflammasome activity.

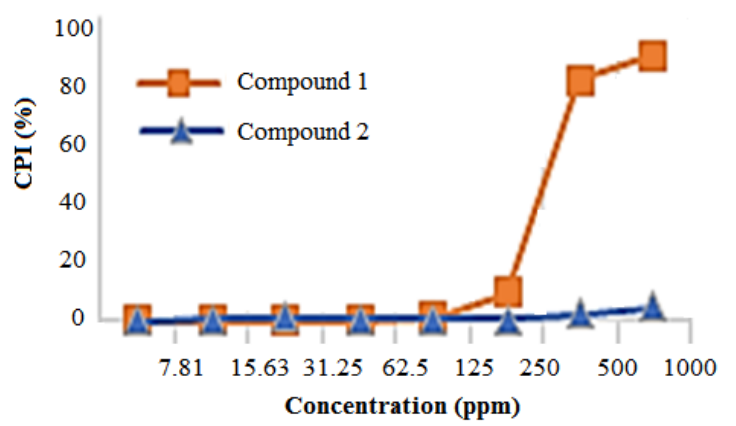

Figure 3. Effects of $24 \mathrm{~h}$ treatment various concentrations of compound $\mathbf{1}$ and $\mathbf{2}$ to HeLa cervical cancer cell (CPI: cell proliferation inhibition)

\section{CONCLUSIONS}

Two steroid compounds, ergosterol peroxide (1) and stigmasterol (2) have been isolated from the stembark of Aglaia simplicifolia and were shown for the first time in this species. The presence of peroxide in steroid structure plays an important role in cytotoxic activity against HeLa cervical cancer cells.

\section{ACKNOWLEDGMENTS}

This work was supported by Directorate General of Higher Education, Ministry of Research, Technology and Higher Education, Indonesia (Postgraduate Grant, 2016-2018 by Unang Supratman) and Directorate General of Higher Islamic Education, Ministry of Religion Indonesia (Prosale Program, Mora Scholarship).

\section{REFERENCES}

Awang K, Loong XM, Leong KH, Supratman U, Litaudon M, Mukhtar MR, Mohamad K. 2012. Triterpenes and steroids from the leaves of Aglaia exima (Meliaceae). Fitoterapia 83:1391-1395.
Cai X, Wang Y, Zhao P, Li Y, Luo X. 2010. Dolabellane diterpenoids from Aglaia odorata. Phytochemistry. 71:1020-1024.

Cayme J, Ragasa C. 2004. Structure elucidation of stigmasterol and - sitosterol from Sesbania grandiflora (Linn). Pers and -carotene from Heliotropium indicum Linn by NMR spectroscopy. Journal Kimika. 20:5-12.

Farabi K, Harneti D, Nurlelasari, Maharani R., Hidayat AC, Awang K., Supratman U, Shiono Y. 2017. New cytotoxic protolimonoids from the stem bark of Aglaia argentea (Meliaceae). Phytochemistry Letters. 21:211-215.

Harneti D, Supratman U. 2021. Phytochemistry and biological activities of Aglaia species. Phytochemistry 181:112540

Harneti D, Supriadin A, Ulfah M, Safari A, Supratman U, Awang K, Hayashi H. 2014. Cytotoxic constituents from the bark of Aglaia eximia (Meliaceae). Phytochem. Lett. 8:28-31.

Harneti D, Tjokronegoro R, Safari A, Supratman U, Loong XM, Mukhtar MR, Mohamad K, Awang K, Hayashi H. 2012. Cytotoxic triterpenoids from the bark of Aglaiasmithii. Phytochemistry Letters. 5:496-499.

Heyne K. 1982. The Useful Indonesian Plants. Jakarta: Ministry of Forestry.

Hidayat AT, Farabi K, Harneti D, Nurlelasari, Maharani R, Mayanti T, Supratman U, Shiono Y. 2017a. A Cytotoxic Rocaglate Compound from The Stembark of Aglaia argentea (Meliaceae). Molekul. 2:146-152.

Hidayat AT, Farabi K, Harneti D, Maharani R, Darwati, Nurlelasari, Mayanti T, Arlette SSAS, Supratman U, Shiono Y. 2017b. Cytotoxicity and Structure Activity Relationship of DammaraneTypeTriterpenoids from the Bark of Aglaia elliptica against P-388 Murine Leukemia Cells. Natural Product Sciences. 4:291-298.

Joycharat N, Plodpai P, Panthong K, Yingyongnarongkul B, Voravuthikunchai SP. 2010. Terpenoid constituents and antifungal activity of Aglaia forbesii seed against phytopathogens. Canadian Journal of Chemistry. 88:937-944.

Kurniasih N, Milawati H, Fajar M, Hidayat AT, Abdulah R, Harneti D, Supratman U, Azmi 
MN. 2018. Sesquiterpenoid Compounds from The Stembark of Aglaia minahassae (Meliaceae). Molekul. 13 (1):56-62.

Kurniasih N, Supriadin A, Fajar M, Abdulah R, Harneti D, Supratman U, Azmi MN. 2019. Cytotoxic sesquterpenoid compound from the stembark of Aglaia simplicifolia (Meliaceae). J. Phys.: Conf. Ser. 1402 055037

Leong KH, Looi CY, Loong XW, Cheah FK, Supratman U, Litaudon M, Mohd Rais Mustafa MR, Awang K. 2016. Cycloart-24ene-26-ol-3-one, a New Cycloartane Isolated from Leaves of Aglaia exima Triggers Tumour Necrosis Factor- Receptor 1-Mediated Caspase-Dependent Apoptosis in Colon Cancer Cell Line. PLOS ONE. 4:1-17.

Liu S, Liu SB, Zuo W, Guo Z, Mei W, Dai H. 2014. New sesquiterpenoids from Aglaia odorata var. microphyllina and their cytotoxic activity. Fitoterapia. 92:93-99.

Nowak R, Drozd M, Mendyk E, Lemieszek M, Krakowiak O, Kisiel W, Rzeski W, Szewczyk K, 2016. A New Method for the Isolation of Ergosterol and Peroxyergosterol as Active Compounds of Hygrophoropsis aurantiaca and in Vitro Antiproliferative Activity of Isolated Ergosterol Peroxide. Molecules. 21: 946

Nugroho BW, Edrada RA, Wray V, Witte L, Bringmann G, Gehling M, Proksch P. 1999. An insectisidal rocaglamida derivates and related compounds from Aglaia odorata (Meliaceae). Phytochemistry. 51:367-376.

Pan L, Kardono LBS, Riswan S, Chai H, Carcache de Blanco EJ, Pannell CM, Soejarto DD, McCloud TG, Newman DJ, Kinghorn AD. 2010. Isolation and characterization of minor analogues of silvestrol and other constituents from a large-scale re-collection of Aglaia foveolata. Journal of Natural Products. 4: 1873-1878.

Sianturi J, Harneti D, Darwati, Mayanti T, Supratman U, Awang K. 2016. A New(-)5',6-dimethoxyisolariciresinol-(3",4"dimethoxy)-3 $\alpha-O-\beta$-glucopyranoside from the bark of Aglaia eximia (Meliaceae). Natural Products Research. 30:2204-2208.
Sittampalam GS, Coussens NP, Brimacombe K, Grossman A, Arkin M, Auld D, Austin C, Baell J, Bejcek B, Caaveiro JMM, Chung TDY, Dahlin JL, Devanaryan V, Foley TL, Glicksman M, Hall MD, Haas JV, Inglese J, Iversen PW, Kahl SD, Kales SC, Lal-Nag M, Li Z, McGee J, McManus O, Riss T, Trask Jr O J, Weidner JR, Wildey MJ, Xia M, Xu X. 2018. Assay Guidance Manual. Eli Lilly \& Company and the National Center for Advancing Translational Sciences Bethesda (MD).

Su B, Chai H, Mi Q, Riswan S, Kardono LBS, Afriastini JJ, Santarsiero BD, Mesecar AD, Fransworth NR, Cordell GA, Swanson SM, Kinghorn D. 2006. Activity-guided isolation of cytotoxic constituents from the bark of Aglaiacrassinervia collected in Indonesia. Bioorganic and Medicinal Chemistry. 14:960-972.

Wood D L, Silverstain R M \& Nakajima M. 1970. Control of Insects Behavior by Natural Product. New York: Academic Press.

Wu HY, Yang FL, Li LH, Rao YK, Ju TC, Wong WT, Hsieh CY, Pivkin MV, Hua KF, Wu SH. 2018. Ergosterol peroxide from marine fungus Phoma sp. induces ROS-dependent apoptosis and autophagy in human lung adenocarcinoma cells. Scientific Reports 8:17956

Xie BJ, Yang SP, Chen HD, Yue JM. 2007. Triterpenoids from Aglaia duperreana. Journal of Natural Products. 70:1532-1535.

Yodsaoue O, Sonprasit J, Karalai C, Ponglimanont C, Tewtrakul S, Chantrapromma S. 2012. Diterpenoids and triterpenoids with potential anti-inflammatory activity from the leaves of Aglaia odorata. Phytochemistry. 76:83-91.

Zhang F, Wang JS, Gu YC, Kong LY. 2010. Triterpenoids from Aglaia abbreviata and their cytotoxic activities. Journal of Natural Products. 73:2042-2046.

Zhang F, Zhu Y, Li Q, Cen J. 2016. Four New Pregnane Steroids from Aglaia abbreviate and Their Cytotoxic Activities. Helv. Chim. Acta. 99:73-77. 